\title{
Bioactive compounds and antioxidant activity evolution during the ripening process of 12 Opuntia spp. fruit accessions
}

\author{
José Manuel Pinedo-Espinoza ${ }^{1,3}$, Cesar Leobardo Aguirre-Mancilla ${ }^{3}$, Rubén Jiménez- \\ Alvarado ${ }^{2}$, Juan Carlos Raya-Pérez ${ }^{3}$, Gabriel Iturriaga ${ }^{3}$, Juan Gabriel Ramírez-Pimentel ${ }^{3}$, \\ Alma Delia Hernández-Fuentes ${ }^{2 *}$

\begin{abstract}
'Universidad Autónoma de Zacatecas, Unidad Académica de Agronomía, km 15.5 Carretera Zacatecas-Guadalajara, C.P. 98170, Zacatecas, Zacatecas, México, ${ }^{2}$ Universidad Autónoma del Estado de Hidalgo, Instituto de Ciencias Agropecuarias. Av. Universidad km 1 Rancho Universitario, C. P. 43000, Tulancingo de Bravo, Hidalgo, ${ }^{3}$ Tecnológico Nacional de México, Instituto Tecnológico de Roque, México. Km 8 Carretera Celaya-Juventino Rosas, Apartado Postal 508, C. P. 38110
\end{abstract}

\section{A B S TR A C T}

Opuntia spp. is easily adaptable to arid and semiarid climates, and represents a valuable alternative for the agricultural development in dry regions. The aim of this work was to know the evolution of bioactive compounds concentration such as phenolics, flavonoids and pigments (Isobetanins, betanins, indicaxanthins and total betalains) during the ripening process of twelve accessions of Opuntia spp. fruits. DPPH and ABTS radical scavenging capacity were determined and correlated with pigments and bioactive compounds concentration. Bioactive compounds and pigments concentration increased along ripening. Higher concentration of total betalains were found in ripe 'Bonda' (O. guerrana Griffiths) and 'Rojo Toluca' (Opuntia robusta var. Larreyi) accessions, being of $78.96 \pm 0.54 \mathrm{mg}^{100} \mathrm{~g}^{-1} \mathrm{DW}$ and

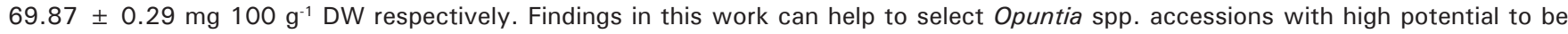
established as a valuable crop in the arid zones of Mexico.

Keywords: Antioxidant activity; Betalains; Bioactive compounds; Cactus pear; Opuntia spp.

\section{INTRODUCTION}

The genus Opuntia comprises approximately three hundred species. They belong to the family Cactaceae, which are plants that utilize water efficiently, even five times more than conventional crops, requiring low amounts of water. For these reasons, Opuntia spp. are easily adaptable to arid and semiarid regions, and have been considered by the FAO as a valuable alternative for the agricultural development in dry regions where the rains are scarce (Pimienta, 2001). This plant is cultivated in Mexico, Italy, South Africa and other countries, with different species of Opuntia predominating in each country, and it is well known that the weather, region and cultural practices can affect the content of nutrients and mineral composition, as well as quantities of bioactive compounds in plants. However, there are some differences among the cultivars respect to their fruits, such as size, maturation time and number of seeds. Recently, Opuntia spp. has gained considerable attention due to the bioactive components it contains, and many researchers have contributed to the characterization of Opuntia spp. fruits (prickly pear fruits), and they have extracted natural pigments not only from their pulp but also from their skin. Stintzing (2005), published information about antioxidants and phytochemicals present in fruits of different cultivars of Opuntia ficus-indica (L.) Mill. The Opuntia stricta fruit showed an intense purple color due to its high concentration of betacyanins $(80 \mathrm{mg} / 100 \mathrm{~g}$ of fresh weight) (Castellar, 2003). Moreover, juice of Opuntia stricta fruit (fresh, dried or concentrated) can be used as a natural food ingredient, and the pigments, antioxidants and others bioactive compounds it contains, help to improve the overall quality of the final food product in which it is added, increasing the acceptability of the consumer (Castellar, 2003;

*Corresponding author:

Alma Delia Hernández-Fuentes, Universidad Autónoma del Estado de Hidalgo, Instituto de Ciencias Agropecuarias. Av. Universidad km 1

Rancho Universitario, C. P. 43000, Tulancingo de Bravo, Hidalgo. Phone/Fax: +52 01 (771) 717 2000. E-mail: hfad@hotmail.com

Received: 29 September 2016;

Revised: 26 January 2017;

Accepted: 28 January 2017;

Published Online: 03 February 2017 
Castellar, 2006; Obón, 2009). These compounds differ depending upon the species and clones studied, and they have not been completely explored. In comparison with beet root, where betalains can also be found, prickly pear fruits offer a wide variety of colors, which could be used in foods due to its natural character (Stintzing et al., 2002). Some species of the genus Opuntia have shown bioactivity as analgesic, anti-inflammatory, antioxidant, hypoglycemic, and neuroprotective effect, and could be useful in cancer chemoprevention (Tesoriere et al., 2005; Bensadón, 2010). The fresh prickly pear fruits are used to elaborate different products as jams, candies, liqueurs, sauces and juices among others. Nevertheless, some species of the genus Opuntia produce red fruits containing big seeds or a large number of seeds, which are not consumed by people but there is a great interest about they in order to obtain natural pigments for food applications, because the opening of new markets for functional food and beverage industry has become an important area of opportunity (Mobhammer et al., 2005 and Stintzing, 2007). In order to know what specie and ripening state produces the highest concentration of pigments and bioactive compounds, the record of changes in their concentration along the maturity time is very important. It has been reported that pigmentation of red prickly pear fruits occurs first in the center, long before fruit ripening and skin pigmentation. Pigmentation is full when the fruit is ripe, and it is correlated with the maximum content of total soluble solids (Felker et al., 2008). Therefore, an adequate ripening state at the moment of the harvest is very important for the fruit quality. For these reasons, the aim of this work was to know changes in pigments content and antioxidant compounds occurring along the ripening of twelve accessions of red prickly pear fruits.

\section{MATERIALS AND METHODS}

\section{Plant material}

Twelve accessions of Opuntia spp. red prickly pears: 'Cacalote' (O. cochinera Griffiths), 'Bonda' (O. guerrana Griffiths), 'Rojo Toluca' (Opuntia robusta var. Larreyi), 'Tapón Aguanoso' (O. robusta var. robusta), 'Grifa' (Opuntia megacantha Salm-Dick), 'Rojo Insurgentes' (O. megacantha Salm-Dick), 'Orejón' (O. megacantha Salm-Dick), 'Sangre de Toro' (O. megacantha Salm-Dick), 'Cardona' (O. streptacantha Lem.), 'Rojo Pelón' (O. ficus indica (L.) Mill.), 'Sandía' (Opuntia streptacantha) and 'Burra la Cruz' (O. robusta var. robusta), were harvested from the National Repository of Opuntias, in the Regional North-central Universitary Center (CRUCEN-Zacatecas) of the Autonomous University Chapingo, in Zacatecas, Zacatecas, Mexico, located at $22^{\circ} 44^{\prime} 49.6^{\prime \prime}$ North latitude and $102^{\circ} 46^{\prime} 28.2^{\prime \prime}$ West longitude; at an altitude of 2,296 meters above sea level. The characteristic climate of this region is classified as BS1 kw(w), which corresponds to a dry climate, the least dry of the BS, with an annual average temperature ranging between 12 and $18{ }^{\circ} \mathrm{C}$, and an annual average rainfall of $472 \mathrm{~mm}$. Most of the rainfall (65\%) occurs from June to August.

\section{Chemicals}

Liquid chromatography grade solvents: Acetone, methanol, and acetonitrile were purchased from EMD Millipore Chemicals (Billerica, MA, USA), and formic acid, glacial acetic acid, and phosphoric acid were obtained from Anachemia (Canada). Ultrapure water was obtained from a Millipore Milli-Q water purification system (Billerica, MA, USA).

Gallic acid, Sephadex-LH-20, 2,2-azobis (2-methylproprionamidine) dihydrochloride, FolinCiocalteu reagent, sodium carbonate, quercetin, epicatechin, p-hydroxybenzoic acid, protocatechuic acid, p-coumaric acid, m-coumaric acid, caffeic acid, ferulic acid, shikimic acid, ellagic acid, and 5-caffeoylquinic acid were purchased from Sigma-Aldrich (St. Louis, MO, USA).

\section{Fruits harvesting and samples preparation}

The twelve prickly pear accessions 'Cacalote' (CL), 'Bonda' (BO), 'Rojo Toluca' (RT), 'Tapón Aguanoso' (TA), 'Grifa' (GR), 'Rojo Insurgentes' (RI), 'Orejón' (OR), 'Sangre de Toro' (ST), 'Cardona' (CA), 'Rojo Pelón' (RP), 'Sandía' (SA) and 'Burra la Cruz' (BC) were harvested during eight dates after anthesis until their complete ripe. Fifty fruits were randomly collected from five plants (ten of each). Samples were codified as $A_{D}$, where A means the prickly pear accession, and the subscript $\mathrm{D}$ means the days after anthesis, resulting 96 samples. Fruits were ultrafreezed at $-70{ }^{\circ} \mathrm{C}$ (Ultrafreezer THERMO SCIENTIFIC 303, USA) and lyophilized at $133 \times 10^{-3} \mathrm{mBar}$ for quantification of total phenolics, total flavonoids, antioxidant activity, and betalains. Lyophilized samples were ground in a cutter mill (RTSCH GM 200, Germany) at $9000 \mathrm{rpm}$ per $50 \mathrm{~s}$ until a fine powder of $150 \mathrm{~mm}$ was obtained.

\section{Maturity index}

The fruits were washed carefully with distilled water in order to eliminate the glochids. The images of each longitudinally cut fruit were recorded in photographs in order to make a comparison between them. These observations together with the external color of the fruits allowed the establishment of a visual scale with the following five values: 1) very immature; 2) immature; 3) moderately mature and 4) mature (Fig. 1).

\section{Total phenolics content}

The total phenolics content (TPC) was determined according to the Folin-Ciocalteu method (Waterman and 
Mole, 1994) with slight modifications. A lyophilized sample of $0.5 \mathrm{~g}$ was mixed with $20 \mathrm{~mL}$ of $80 \%$ methanol and vortexed per $10 \mathrm{~min}$. After which, it was centrifuged at $17500 x g$ per $10 \mathrm{~min}$ at $5^{\circ} \mathrm{C}$ (centrifuge Thermo Scientific Mod. ST 16R, Germany). $1 \mathrm{~mL}$ of the supernatant was mixed with $5 \mathrm{~mL}$ of the Folin-Ciocalteu reagent diluted 1:10 $(\mathrm{v}: \mathrm{v})$ with distilled water and it was left stand per $7 \mathrm{~min}$. $4 \mathrm{~mL}$ of a solution of sodium carbonate $(7.5 \%)$ was added and left to react in the darkness per $2 \mathrm{~h}$. The absorbance was measured at $760 \mathrm{~nm}$ using a spectrophotometer (Jenway 6715 UV/VIS, Jenway Techne Inc. USA). A calibration curve was prepared using gallic acid as standard. Results were expressed as mg Gallic Acid Equivalents (GAE)/g Fresh Weight (FW). Moisture of fresh fruits was used to convert from dry weight to fresh weight. All the experiments were done by triplicate.

\section{Total flavonoids content}

The total flavonoids content was determined according to the method described by Dowd and adapted by Arvouet-Grand et al., (1994). Briefly, $0.1 \mathrm{~g}$ of lyophilized sample was mixed with $10 \mathrm{~mL}$ of $80 \%$ methanol; this mixture was vortexed $10 \mathrm{~min}$ and filtered through filter paper Whatman grade 1. After which, $2 \mathrm{~mL}$ of filtrate was mixed with $2 \mathrm{~mL}$ of a methanolic solution of $\mathrm{AlCl}_{3}(2 \%$ in methanol). This mixture was left stand for $20 \mathrm{~min}$ in the darkness. The absorbance was measured at $415 \mathrm{~nm}$ using a spectrophotometer (Jenway 6715 UV/VIS, Jenway Techne Inc. USA). A calibration curve was prepared $(0-40 \mathrm{mg} / \mathrm{L})$ using quercetin as standard. Results were expressed as $\mathrm{mg}$ Equivalents of Quercetin (EQ)/100 g of Fresh Weight $(\mathrm{FW})$. Moisture of fresh fruits was used to convert from dry weight to fresh weight.

\section{Preparation of samples for radical scavenging capacity assays}

$0.5 \mathrm{~g}$ of lyophilized fruit was mixed with $20 \mathrm{~mL}$ of $80 \%$ methanol. This mixture was vortexed per $20 \mathrm{~min}$ and centrifuged at $17500 \times \mathrm{xg}$ per $10 \mathrm{~min}$ at $5^{\circ} \mathrm{C}$ in a centrifuge (Thermo Scientific Mod. ST 16R, Germany). The supernatant was used for the determination of radical scavenging assays.

\section{DPPH radical scavenging capacity}

The radical scavenging capacity was performed by the DPPH method described by Brand-Williams et al., (1995). Briefly, $0.5 \mathrm{~mL}$ of sample was mixed with a methanolic solution of DPPH $\left(6 \times 10^{-5} \mathrm{M}\right)$, which was previously left to stand per $2 \mathrm{~h}$ under constant agitation in the darkness. The mixture was vortexed $15 \mathrm{~s}$ and left to stand in the darkness per $1 \mathrm{~h}$ at $4^{\circ} \mathrm{C}$. Absorbance was measured in a spectrophotometer (Jenway 6715 UV/VIS, Jenway Techne Inc. USA) at $515 \mathrm{~nm}$. Trolox was used as standard, and results were expressed as mmol Trolox equivalents (TE)/g fresh weight $(\mathrm{FW})$. Moisture of fresh fruits was used to convert from dry weight to fresh weight.

\section{ABTS radical scavenging capacity}

The radical scavenging capacity was determined by the ABTS assay described by Re, et al., (1999) with slight modifications. An aqueous solution of ABTS $(7 \mathrm{mM})$ was mixed with an aqueous solution of potassium persulfate $(2.45 \mathrm{mM})$ at $1: 1(\mathrm{v}: \mathrm{v})$ ratio. This mixture was left in the darkness under constant agitation during $16 \mathrm{~h}$ in order to produce the ABTS radical $\left(\mathrm{ABTS}^{+}\right)$. The solution containing $\mathrm{ABTS}^{+}$was diluted with acetate buffer until reach an absorbance value of $0.700 \pm 0.02$ at $754 \mathrm{~nm} .100$ $\mathrm{mL}$ of the extract was added to $3900 \mathrm{~mL}$ of the $\mathrm{ABTS}^{+}$ solution. The absorbance was measured at $754 \mathrm{~nm}$ after 6 min storing the mixture in the darkness. Trolox was used as standard preparing a standard curve (0-15 mM Trolox). Results were expressed as Trolox equivalent antioxidant capacity (TEAC) in $\mu \mathrm{M}$ Trolox equivalent (TE) $/ 100 \mathrm{~g}$ fresh weight $(\mathrm{FW})$. Moisture of fresh fruits was used to convert from dry weight to fresh weight.

\section{Analysis of indicaxanthin, betanin and isobetanin Preparation of samples}

Lyophilized samples $(500 \mathrm{mg}$ ) were extracted with $80 \%$ aqueous methanol $(20 \mathrm{~mL})$ in an ultrasonic bath for $20 \mathrm{~min}$ at $37^{\circ} \mathrm{C}$. Then, samples were vortexed 30 seconds and centrifuged (AllegraTM 25R centrifuge) at $4000 x g$ for 4 min at room temperature. The supernatant was placed into a $50 \mathrm{~mL}$ tube. The residue was re-extracted using the same procedure. The supernatants were combined and completed at $50 \mathrm{~mL}$ using water. The mixture was subsequently filtered through a $0.2 \mu \mathrm{m}$ nylon filter and filtrate was assayed for total betalains and specific indicaxanthin, betanin and isobetanin analysis (Kujala et al., 2001).

\section{UPLC-ESI-MS/MS analysis}

The UPLC analysis was performed using a Waters Acquity Ultra-Performance'TM LC system (Waters), equipped with a quaternary pump system (Waters). An Acquity solidcore particle Cortecs column $(150 \mathrm{mmX} 2.1 \mathrm{~mm}$ id, $1.6 \mu \mathrm{m}$ particle size) from Waters was used for the separation. The pigments were separated with a mobile phase that consisted of $2 \%$ Formic acid (eluent A) and acetonitrile (eluent B), The flow-rate was $0.4 \mathrm{~mL} / \mathrm{min}$ and the gradient elution was initial, $2 \% \mathrm{~B}$; 0-6.0 min, isocratic $2 \% \mathrm{~B}$; $6.0-15.0 \mathrm{~min}$, 2-30\% B; 15-15.1 min, 30-100\% B;15.1-18.0 min isocratic $100 \% \mathrm{~B} ; 18.0-18.1 \mathrm{~min} 100-2 \% \mathrm{~B} ; 18.1-23.0 \mathrm{~min}$ isocratic $2 \% \mathrm{~B}$. The MS analyses were carried out on a Xevo TQD mass spectrometer (Waters) equipped with a Z-spray electrospray interface. The analyses were performed in positive mode and the data was acquired through scan mode from 150 to $600 \mathrm{~m} / \mathrm{z}$. Extracted mass of $[\mathrm{M}+\mathrm{H}]^{+}$for 


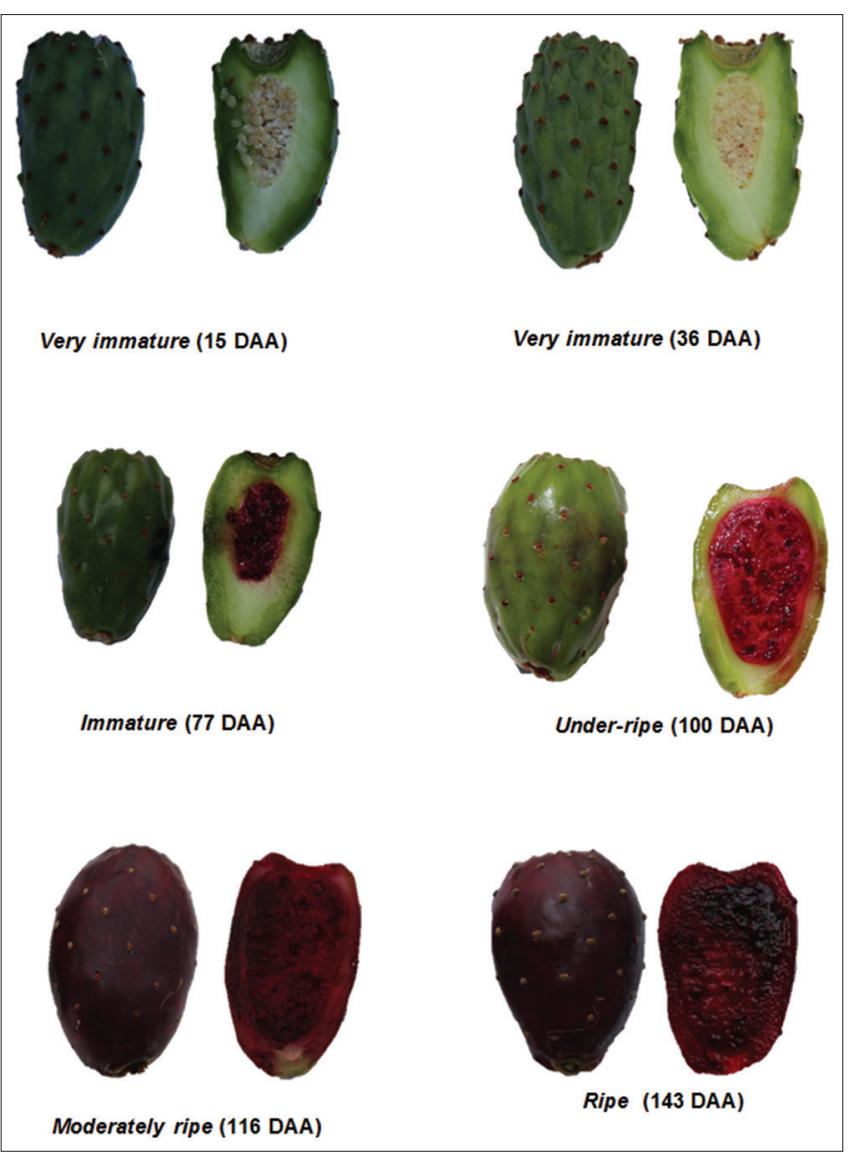

Fig 1. Evolution of internal and external color of 'Orejón' (O. megacantha Salm-Dick) accession, harvested since 15 to 143 days after anthesis (DAA).

indicaxanthin $(309 \mathrm{~m} / \mathrm{z})$, betanin $(551 \mathrm{~m} / \mathrm{z})$ and isobetanin $(551 \mathrm{~m} / \mathrm{z})$ were used for identification and quantification. Betanin and isobetanin were differentiated based on Kujala et al. (2002) elution order. Molecules were quantified as betanin equivalent. The ionization source parameters were capillary voltage, $3.5 \mathrm{kV}$; source temperature, 110 ${ }^{\circ} \mathrm{C}$ and desolvation gas flow rate, $650 \mathrm{~L} / \mathrm{h}$; desolvation temperature, $250{ }^{\circ} \mathrm{C}$. Nitrogen ( $99 \%$ purity) and argon ( $99 \%$ purity) were used as nebulizing and collision gases, respectively. Data acquisition was carried out with the MassLynx 4.1 software.

\section{Quantification of total betalains}

Betalains content was calculated according to Tsai et al. (2011) with slight modifications (Equation 3). All determinations were performed on a UV/Vis spectrometer (Helios, Thermo). The UV/vis absorption spectra were recorded at $536 \mathrm{~nm}$.

Betalains $(\mathrm{mg} / \mathrm{g})=\frac{\mathrm{Abs} \times \mathrm{MW} \times \mathrm{DF} \times \mathrm{V}}{\varepsilon \times \mathrm{L} \times \mathrm{W}}$

Where Abs is the absorbance value at a wavelength of $536 \mathrm{~nm}$ for betacyanins, DF is the dilution factor, $\mathrm{V}$ is the volume of solution $(\mathrm{mL}), \mathrm{W}$ is the dry weight $(\mathrm{g})$, and $\mathrm{L}$ is the path-length $(1 \mathrm{~cm})$ of the cuvette. The molecular weight $(\mathrm{MW}=550 \mathrm{~g} / \mathrm{mol})$ and the molar extinction coefficient $(\varepsilon=61,600 \mathrm{~L} / \mathrm{mol} \mathrm{cm}$ ) were applied in order to quantify betalains.

\section{Statistical analysis}

A completely randomized design was used. Means and standard deviations were calculated. The statistical software SAS (software JMP 5.0, V. 9.0) (2002) was used for the analysis of variance (ANOVA). The Tukey test was used for the comparison of means $(P \leq 0.05)$ with a $95 \%$ of confidence. Correlation analysis was carried out using Pearson's correlation coefficient. All the experiments except maturity, size and color were done by triplicate.

\section{RESULTS AND DISCUSSION}

\section{Changes in pigments concentration during the ripening}

Pigments (isobetanins, betanins, and indicaxanthins) were detected in immature fruits $\mathrm{BO}_{63}, \mathrm{RT}_{63}, \mathrm{CL}_{77}, \mathrm{RI}_{77}, \mathrm{OR}_{77}$ and $\mathrm{CA}_{77}$ (Table 1). Nevertheless, in the other accessions, the pigments appeared until the fruits were under-ripe, as in $\mathrm{TA}_{100}, \mathrm{GR}_{100}, \mathrm{RP}_{100}, \mathrm{SA}_{100}$ and $\mathrm{BC}_{100}$ or even until they were moderately ripe as $\mathrm{ST}_{116}$. Betacyanin was the main pigment found in these fruits, meanwhile lower levels of isobetanins, betanins and indicaxanthins were found. The highest concentration of isobetanins was found in ripe fruits, being of $3.58 \pm 0.15 \mathrm{mg} / 100 \mathrm{~g}$ dry basis (DB) and $4.58 \pm 0.38 \mathrm{mg} / 100 \mathrm{~g} \mathrm{DB}$ for $\mathrm{BO}_{143}$ and $\mathrm{RT}_{143}$ respectively. The accessions $\mathrm{BO}_{143}$ and $\mathrm{RT}_{143}$ showed also the highest concentrations of betanins (45.71 and $38.09 \pm 1.81 \mathrm{mg} / 100 \mathrm{~g}$ DB respectively) and indicaxanthins (29.67 \pm 0.45 and $27.20 \pm 0.10 \mathrm{mg} / 100 \mathrm{~g} \mathrm{DB}$ respectively). Therefore, the highest concentration of total betalains was found in $\mathrm{BO}_{143}$ and $\mathrm{RT}_{143}$, being of $78.96 \pm 0.54$ and

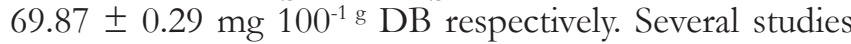
highlight the antioxidant properties of betalains and the importance of Opuntia spp. fruits containing high levels of these bioactive compounds (Fernández-López et al., 2010; Sumaya-Martínez et al., 2011). Moreover, significantly positive correlations were found between the DPPH or ABTS radical scavenging activity and pigments concentration for these two accessions (Tables 4 and 5). These results indicate that the free radical scavenging activity was increased directly proportional to the increment of pigments concentration in all accessions. So it can be inferred that these pigments play an important role on the antioxidant activity showed by BO and RT accessions, nevertheless the Opuntia spp. fruits contain other compounds with antioxidant activity such as phenolics. These pigments are appreciated as nutraceutical ingredients since they promote health and prevent illnesses due to their 
Table 1: Evolution of isobetanin, betanin, indicaxanthin and total betalains of twelve red prickly pear fruit accessions from very immature to ripe

\begin{tabular}{|c|c|c|c|c|}
\hline $\begin{array}{l}\text { Days after anthesis } \\
\text { (DAA) }\end{array}$ & 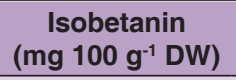 & 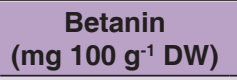 & $\begin{array}{c}\text { Indicaxanthin } \\
\left.\text { (mg } 100 \mathrm{~g}^{-1} \mathrm{DW}\right)\end{array}$ & 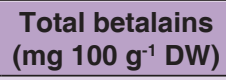 \\
\hline \multicolumn{5}{|l|}{ 'Cacalote' } \\
\hline $15-63$ & $0.0 \pm 0.0^{\mathrm{e}}$ & $0.0 \pm 0.0^{e}$ & $0.0 \pm 0.0^{c}$ & $0.0 \pm 0.0^{\mathrm{e}}$ \\
\hline 77 & $0.22 \pm 0.01^{d}$ & $0.94 \pm 0.14^{d}$ & $0.0 \pm 0.0^{c}$ & $1.17 \pm 0.15^{d}$ \\
\hline 100 & $0.83 \pm 0.05^{c}$ & $4.03 \pm 0.06^{c}$ & $0.0 \pm 0.0^{c}$ & $4.11 \pm 0.11^{c}$ \\
\hline 116 & $2.45 \pm 0.02^{b}$ & $19.84 \pm 0.05^{b}$ & $8.54 \pm 0.04^{b}$ & $29.83 \pm 0.08^{b}$ \\
\hline 143 & $3.33 \pm 0.04^{\mathrm{a}}$ & $26.63 \pm 0.24^{a}$ & $18.23 \pm 0.05^{a}$ & $48.19 \pm 0.26^{a}$ \\
\hline Correlation with DDPH & $0.948^{*}$ & $0.924^{\star}$ & $0.882^{*}$ & $0.917^{*}$ \\
\hline Correlation with $\mathrm{ABTS}$ & $0.979^{*}$ & $0.965^{*}$ & $0.918^{*}$ & $0.956^{*}$ \\
\hline \multicolumn{5}{|l|}{ 'Bonda' } \\
\hline $15-49$ & $0.0 \pm 0.0^{e}$ & $0.0 \pm 0.0^{e}$ & $0.0 \pm 0.0^{e}$ & $0.0 \pm 0.0^{f}$ \\
\hline 63 & $1.38 \pm 0.03^{d}$ & $25.20 \pm 0.11^{d}$ & $3.90 \pm 0.01^{d}$ & $30.48 \pm 0.15^{\mathrm{e}}$ \\
\hline 77 & $2.08 \pm 0.03^{c}$ & $36.74 \pm 0.26^{c}$ & $5.41 \pm 0.04^{c}$ & $44.23 \pm 0.32^{d}$ \\
\hline 100 & $3.05 \pm 0.03^{b}$ & $40.17 \pm 0.08^{b}$ & $15.75 \pm 0.10^{b}$ & $58.97 \pm 0.15^{c}$ \\
\hline 116 & $3.12 \pm 0.02^{b}$ & $40.38 \pm 0.13^{b}$ & $29.62 \pm 0.26^{a}$ & $73.12 \pm 0.36^{b}$ \\
\hline 143 & $3.58 \pm 0.15^{a}$ & $45.71 \pm 0.05^{a}$ & $29.67 \pm 0.45^{a}$ & $78.96 \pm 0.54^{a}$ \\
\hline Correlation with DDPH & $0.988^{*}$ & $0.961^{*}$ & $0.925^{\star}$ & $0.988^{*}$ \\
\hline Correlation with $\mathrm{ABTS}$ & $0.946^{*}$ & $0.895^{*}$ & $0.968^{*}$ & $0.987^{*}$ \\
\hline \multicolumn{5}{|l|}{ 'Rojo Toluca' } \\
\hline $15-49$ & $0.0 \pm 0.0^{\mathrm{e}}$ & $0.0 \pm 0.0^{d}$ & $0.0 \pm 0.0^{f}$ & $0.0 \pm 0.0^{\mathrm{e}}$ \\
\hline 63 & $1.79 \pm 0.07^{\mathrm{d}}$ & $2.60 \pm 0.06^{d}$ & $10.66 \pm 0.15^{e}$ & $15.05 \pm 0.15^{d}$ \\
\hline 77 & $2.45 \pm 0.07^{c}$ & $16.42 \pm 0.04^{c}$ & $13.26 \pm 0.06^{d}$ & $32.13 \pm 0.17^{c}$ \\
\hline 100 & $2.61 \pm 0.03^{c}$ & $30.07 \pm 0.16^{b}$ & $14.30 \pm 0.08^{c}$ & $46.98 \pm 0.20^{b}$ \\
\hline 116 & $3.74 \pm 0.05^{b}$ & $32.32 \pm 0.90^{\mathrm{b}}$ & $23.53 \pm 0.11^{\mathrm{b}}$ & $61.59 \pm 0.26^{a}$ \\
\hline 143 & $4.58 \pm 0.34^{a}$ & $38.09 \pm 1.81^{a}$ & $27.20 \pm 0.10^{\mathrm{a}}$ & $69.87 \pm 0.29^{a}$ \\
\hline Correlation with DDPH & $0.925^{\star}$ & $0.985^{\star}$ & $0.833^{*}$ & $0.967^{*}$ \\
\hline Correlation with $\mathrm{ABTS}$ & $0.957^{*}$ & $0.939^{*}$ & $0.894^{*}$ & $0.969^{*}$ \\
\hline \multicolumn{5}{|l|}{ 'Tapon Aguanoso' } \\
\hline $15-77$ & $0.0 \pm 0.0^{c}$ & $0.0 \pm 0.0^{d}$ & $0.0 \pm 0.0^{c}$ & $0.00^{d}$ \\
\hline 100 & $0.85 \pm 0.02^{b}$ & $5.34 \pm 0.22^{c}$ & $0.0 \pm 0.0^{c}$ & $6.190 .22^{c}$ \\
\hline 116 & $3.75 \pm 0.10^{a}$ & $34.25 \pm 0.28^{b}$ & $6.11 \pm 0.03^{b}$ & $44.110 .30^{b}$ \\
\hline 143 & $3.79 \pm 0.15^{\mathrm{a}}$ & $36.34 \pm 0.11^{\mathrm{a}}$ & $6.46 \pm 0.07^{\mathrm{a}}$ & $46.590 .24^{\mathrm{a}}$ \\
\hline Correlation with DDPH & $0.817^{\star}$ & $0.839^{*}$ & $0.832^{*}$ & $0.836^{*}$ \\
\hline Correlation with $\mathrm{ABTS}$ & $0.903^{*}$ & $0.920^{*}$ & $0.913^{*}$ & $0.918^{*}$ \\
\hline \multicolumn{5}{|l|}{ ‘Grifa' } \\
\hline $15-77$ & $0.0 \pm 0.0^{c}$ & $0.0 \pm 0.0^{c}$ & $0.0 \pm 0.0^{d}$ & $0.0 \pm 0.0^{d}$ \\
\hline 100 & $0.37 \pm 0.03^{b}$ & $2.56 \pm 0.61^{b}$ & $3.11 \pm 0.02^{c}$ & $6.04 \pm 0.64^{c}$ \\
\hline 116 & $0.34 \pm 0.05^{b}$ & $6.14 \pm 0.04^{a}$ & $12.17 \pm 0.09^{b}$ & $18.65 \pm 0.10^{b}$ \\
\hline 143 & $0.53 \pm 0.04^{a}$ & $6.31 \pm 0.17^{\mathrm{a}}$ & $21.67 \pm 0.08^{a}$ & $28.51 \pm 0.24^{a}$ \\
\hline Correlation with DDPH & 0.756 & $0.800^{*}$ & $0.984^{\star}$ & $0.971^{*}$ \\
\hline Correlation with $\mathrm{ABTS}$ & 0.647 & $0.897^{*}$ & $0.976^{*}$ & $0.981^{*}$ \\
\hline \multicolumn{5}{|l|}{ 'Rojo Insurgentes' } \\
\hline $15-63$ & $0.0 \pm 0.0 \mathrm{~d}$ & $0.0 \pm 0.0^{e}$ & $0.0 \pm 0.0^{d}$ & $0.0 \pm 0.0^{e}$ \\
\hline 77 & $0.15 \pm 0.01 c$ & $0.49 \pm 0.02^{\mathrm{d}}$ & $0.0 \pm 0.0^{d}$ & $0.64 \pm 0.02^{d}$ \\
\hline 100 & $2.04 \pm 0.07^{b}$ & $9.91 \pm 0.06^{c}$ & $2.72 \pm 0.04^{c}$ & $14.67 \pm 0.06^{c}$ \\
\hline 116 & $2.11 \pm 0.03^{b}$ & $15.00 \pm 0.02^{b}$ & $4.12 \pm 0.06^{b}$ & $21.23 \pm 0.09^{b}$ \\
\hline 143 & $3.36 \pm 0.07^{a}$ & $25.56 \pm 0.06^{a}$ & $22.83 \pm 0.10^{a}$ & $51.75 \pm 0.18^{a}$ \\
\hline Correlation with DDPH & $0.974^{*}$ & $0.983^{*}$ & $0.830^{\star}$ & $0.939^{*}$ \\
\hline Correlation with $\mathrm{ABTS}$ & $0.933^{*}$ & $0.939^{*}$ & $0.823^{*}$ & $0.882^{*}$ \\
\hline \multicolumn{5}{|l|}{ ‘Orejón’ } \\
\hline $15-63$ & $0.0 \pm 0.0^{e}$ & $0.0 \pm 0.0^{e}$ & $0.0 \pm 0.0^{d}$ & $0.0 \pm 0.0^{e}$ \\
\hline 77 & $0.43 \pm 0.02^{d}$ & $2.92 \pm 0.01^{d}$ & $0.0 \pm 0.0^{d}$ & $2.96 \pm 0.02^{d}$ \\
\hline 100 & $0.76 \pm 0.02^{c}$ & $3.70 \pm 0.05^{c}$ & $2.60 \pm 0.01^{c}$ & $7.06 \pm 0.06^{c}$ \\
\hline 116 & $1.62 \pm 0.01^{b}$ & $14.15 \pm 0.06^{b}$ & $4.21 \pm 0.01^{b}$ & $19.98 \pm 0.03^{b}$ \\
\hline 143 & $2.73 \pm 0.15^{\mathrm{a}}$ & $27.22 \pm 0.19^{a}$ & $25.42 \pm 0.19^{\mathrm{a}}$ & $55.37 \pm 0.39^{a}$ \\
\hline Correlation with DDPH & $0.933^{*}$ & $0.891^{*}$ & $0.820^{*}$ & $0.873^{*}$ \\
\hline Correlation with $\mathrm{ABTS}$ & $0.948^{*}$ & $0.924^{*}$ & $0.815^{*}$ & $0.886^{*}$ \\
\hline \multicolumn{5}{|l|}{ 'Sangre de Toro' } \\
\hline $15-100$ & $0.0 \pm 0.0^{c}$ & $0.0 \pm 0.0^{c}$ & $0.0 \pm 0.0^{c}$ & $0.0 \pm 0.0^{c}$ \\
\hline 116 & $0.45 \pm 0.01^{b}$ & $3.05 \pm 0.04^{b}$ & $2.71 \pm 0.02^{b}$ & $6.21 \pm 0.03^{b}$ \\
\hline 143 & $0.88 \pm 0.10^{a}$ & $11.71 \pm 0.26^{a}$ & $8.59 \pm 0.16^{a}$ & $21.18 \pm 0.39^{a}$ \\
\hline Correlation with DDPH & $0.968^{*}$ & $0.988^{*}$ & $0.989^{*}$ & $0.989^{*}$ \\
\hline Correlation with $\mathrm{ABTS}$ & $0.918^{*}$ & $0.923^{*}$ & $0.923^{*}$ & $0.824^{*}$ \\
\hline
\end{tabular}




\begin{tabular}{|c|c|c|c|c|}
\hline $\begin{array}{l}\text { Days after anthesis } \\
\text { (DAA) }\end{array}$ & 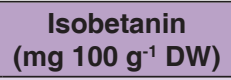 & $\begin{array}{c}\text { Betanin } \\
\left.\text { (mg } 100 \mathrm{~g}^{-1} \mathrm{DW}\right) \\
\end{array}$ & 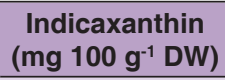 & $\begin{array}{l}\text { Total betalains } \\
\left(\mathrm{mg} 100 \mathrm{~g}^{-1} \mathrm{DW}\right)\end{array}$ \\
\hline \multicolumn{5}{|l|}{ 'Cardona' } \\
\hline $15-63$ & $0.0 \pm 0.0^{e}$ & $0.0 \pm 0.0^{e}$ & $0.0 \pm 0.0^{c}$ & $0.0 \pm 0.0^{e}$ \\
\hline 77 & $0.23 \pm 0.01^{d}$ & $0.78 \pm 0.06^{d}$ & $0.0 \pm 0.0^{c}$ & $1.01 \pm 0.06^{d}$ \\
\hline 100 & $0.67 \pm 0.02^{c}$ & $2.12 \pm 0.03^{c}$ & $0.0 \pm 0.0^{c}$ & $2.79 \pm 0.03^{c}$ \\
\hline 116 & $2.16 \pm 0.08^{b}$ & $9.93 \pm 0.03^{b}$ & $2.17 \pm 0.02^{b}$ & $14.26 \pm 0.09^{b}$ \\
\hline 143 & $2.40 \pm 0.02^{\mathrm{a}}$ & $11.28 \pm 0.07^{a}$ & $4.43 \pm 0.11^{\mathrm{a}}$ & $18.11 \pm 0.17^{a}$ \\
\hline Correlation with DDPH & $0.925^{\star}$ & $0.984^{*}$ & $0.991^{*}$ & $0.989^{*}$ \\
\hline Correlation with ABTS & 0.780 & $0.845^{\star}$ & $0.926^{*}$ & $0.927^{*}$ \\
\hline \multicolumn{5}{|l|}{ ‘Rojo Pelón’ } \\
\hline $15-77$ & $0.0 \pm 0.0^{d}$ & $0.0 \pm 0.0^{d}$ & $0.0 \pm 0.0^{d}$ & $0.0 \pm 0.0^{d}$ \\
\hline 100 & $0.04 \pm 0.01^{c}$ & $0.96 \pm 0.02^{c}$ & $1.40 \pm 0.01^{c}$ & $2.41 \pm 0.01^{c}$ \\
\hline 116 & $0.06 \pm 0.02^{b}$ & $1.40 \pm 0.02^{b}$ & $3.21 \pm 0.02^{b}$ & $4.67 \pm 0.02^{b}$ \\
\hline 143 & $0.15 \pm 0.01^{\mathrm{a}}$ & $2.60 \pm 0.06^{\mathrm{a}}$ & $6.52 \pm 0.04^{\mathrm{a}}$ & $9.27 \pm 0.08^{\mathrm{a}}$ \\
\hline Correlation with DDPH & $0.957^{\star}$ & $0.973^{*}$ & $0.984^{*}$ & $0.983^{*}$ \\
\hline Correlation with ABTS & $0.871^{*}$ & $0.917^{*}$ & $0.947^{*}$ & $0.840^{*}$ \\
\hline \multicolumn{5}{|l|}{ 'Sandía' } \\
\hline $15-77$ & $0.0 \pm 0.0^{d}$ & $0.0 \pm 0.0^{d}$ & $0.0 \pm 0.0^{c}$ & $0.0 \pm 0.0^{d}$ \\
\hline 100 & $1.10 \pm 0.01^{c}$ & $5.04 \pm 0.05^{c}$ & $0.0 \pm 0.0 c$ & $6.14 \pm 0.06^{c}$ \\
\hline 116 & $1.20 \pm 0.01^{b}$ & $7.56 \pm 0.38^{b}$ & $1.41 \pm 0.07^{b}$ & $10.17 \pm 0.46^{b}$ \\
\hline 143 & $1.32 \pm 0.04^{\mathrm{a}}$ & $8.10 \pm 0.01^{\mathrm{a}}$ & $4.11 \pm 0.04^{\mathrm{a}}$ & $13.53 \pm 0.07^{a}$ \\
\hline Correlation with DDPH & $0.971^{*}$ & $0.884^{*}$ & $0.983^{*}$ & $0.975^{*}$ \\
\hline Correlation with ABTS & $0.953^{*}$ & $0.944^{*}$ & $0.946^{*}$ & $0.981^{*}$ \\
\hline \multicolumn{5}{|l|}{ ‘Burra la Cruz’ } \\
\hline $15-77$ & $0.0 \pm 0.0^{d}$ & $0.0 \pm 0.0^{d}$ & $0.0 \pm 0.0^{d}$ & $0.0 \pm 0.0^{d}$ \\
\hline 100 & $2.16 \pm 0.12^{c}$ & $7.96 \pm 0.06^{c}$ & $1.31 \pm 0.03 c$ & $11.43 \pm 0.09^{c}$ \\
\hline 116 & $2.33 \pm 0.04^{b}$ & $12.12 \pm 0.03^{b}$ & $5.10 \pm 0.03^{b}$ & $19.55 \pm 0.09^{b}$ \\
\hline 143 & $2.97 \pm 0.11^{\mathrm{a}}$ & $12.37 \pm 0.10^{a}$ & $7.72 \pm 0.15^{\mathrm{a}}$ & $22.46 \pm 0.29^{a}$ \\
\hline Correlation with DDPH & $0.926^{*}$ & $0.837^{\star}$ & $0.969^{*}$ & $0.939^{*}$ \\
\hline Correlation with ABTS & $0.872^{*}$ & $0.913^{*}$ & $0.981^{*}$ & $0.973^{*}$ \\
\hline
\end{tabular}

Means in each column with different letters are statistically different (Tukey, $P \leq 0.05$ ). *: Significant at $P \leq 0.05$. Values are means \pm standard deviations

effect against oxidative stress (Livrea and Tesoriere, 2006). Moreover, the highest content of total betalains can be an indicator of ripeness in prickly pear fruits.

\section{Changes in total phenolics content during the ripening}

TPC increased over the ripening process, ranging between $24.93 \pm 0.26 \mathrm{mg} \mathrm{GAE} / 100 \mathrm{~g} \mathrm{FW}$ for $\mathrm{RT}_{15}$, to $257.77 \pm 0.17 \mathrm{mg} \mathrm{GAE} / 100 \mathrm{~g}$ FW for $\mathrm{GR}_{143}$ (Table 2). Nevertheless, the most significantly increment in TPC was found between 77 and $100 \mathrm{DAA}$, when the fruit was from immature to under-ripe for almost all the accessions except for CL, RT, and TA, whose maximum change in TPC was found between 116 and $143 \mathrm{DAA}$, when the fruit changed from moderately ripe to ripe, and for GR and ST, whose maximum changes in TPC were between 49 and 63 DAA for the former and between 63 and 77 DAA for the latter, when both accessions were immature. The TPC for ripe fruits varied widely among the accessions, showing as low contents as $65.04 \pm 0.17 \mathrm{mg} \mathrm{GAE} / 100 \mathrm{~g} \mathrm{FW}$ in $\mathrm{BO}_{143}$. Nevertheless, they were found also high levels of TPC in six out of the twelve accessions studied $\left(\mathrm{GR}_{143}, \mathrm{OR}_{143}\right.$, $\mathrm{ST}_{143}, \mathrm{CA}_{143}, \mathrm{SA}_{143}$ and $\mathrm{BC}_{143}$ ), showing values higher than $194.69 \pm 0.36 \mathrm{mg} \mathrm{GAE} / 100 \mathrm{~g} \mathrm{FW}$ (found in $\mathrm{BC}_{143}$ ), which are at least twice the TPC displayed by other fruits as peach (Prunus persica(L)Batsch), plum (Prunus salicina var. Santa
Rosa) and nectarine (Prunus persica var. Nectarin) (Gil, et al., 2002; Cantín, et al., 2009; Belhadj, et al., 2016). These high concentrations of phenolics were significantly correlated (positively) with DPPH and/or ABTS radical scavenging activity, except for OR accession, which was not significant neither for DPPH nor for ABTS radical scavenging activity. This result can be due to the antioxidant activity in OR may be influenced mainly by other compounds such as flavonoids or betalains. Variations in TPC could be due to chemical changes of phenolic compounds as the maturation process occurs, and due to genetic variability among the different accessions, since the cultivation conditions were controlled and the climate conditions were the same for all the accessions.

Changes in total flavonoids content during the ripening Significantly statistical differences were found in TFC during the ripening process of fruits, ranging from $0.56 \pm 0.02 \mathrm{mg} \mathrm{EQ} / 100 \mathrm{~g} \mathrm{FW}$ for $\mathrm{SA}_{15}$ to $19.45 \pm$ $0.07 \mathrm{mg}$ EQ/100g FW for $\mathrm{OR}_{143}$ (Table 3). Six out of the twelve accessions studied (GR, RI, OR, CA, RP, and SA) exhibited the biggest change in TFC between 100 and 116 DAA, when the fruits changed from under-ripe to moderately ripe. The accessions $\mathrm{CA}, \mathrm{ST}$, and $\mathrm{BC}$ showed the major change in TFC between 36 and $49 \mathrm{DAA}$, when 
Pinedo-Espinoza, et al:: Bioactive compounds evolution during the ripening

Table 2: Evolution of total phenolics content of twelve red prickly pear fruit accessions from very immature to ripe

\begin{tabular}{|c|c|c|c|c|}
\hline $\begin{array}{l}\text { Days after anthesis } \\
\text { (DAA) }\end{array}$ & 'Cacalote' & $\begin{array}{c}\text { Total phenolics content } \\
\text { (mg GAE/100 g FW) } \\
\text { 'Bonda' }\end{array}$ & 'Rojo Toluca' & 'Tapón Aguanoso' \\
\hline 15 & $31.01 \pm 0.34^{h}$ & $31.58 \pm 0.26^{f}$ & $24.93 \pm 0.26^{i}$ & $30.32 \pm 0.46^{h}$ \\
\hline 36 & $29.60 \pm 0.36^{g}$ & $37.55 \pm 0.52^{\mathrm{ef}}$ & $38.99 \pm 0.43^{9}$ & $34.97 \pm 0.52^{\mathrm{g}}$ \\
\hline 49 & $35.94 \pm 0.36$ & $39.36 \pm 0.43^{\text {de }}$ & $43.46 \pm 0.26^{f}$ & $36.29 \pm 0.26^{f}$ \\
\hline 63 & $40.71 \pm 0.55^{e}$ & $40.82 \pm 0.34^{d}$ & $45.64 \pm 0.34^{e}$ & $39.27 \pm 0.30^{e}$ \\
\hline 77 & $44.38 \pm 0.26^{d}$ & $45.93 \pm 0.50^{c}$ & $48.11 \pm 0.53^{d}$ & $56.43 \pm 0.70^{d}$ \\
\hline 100 & $68.66 \pm 0.40^{c}$ & $57.06 \pm 0.36^{b}$ & $49.83 \pm 0.50^{c}$ & $78.59 \pm 0.43^{c}$ \\
\hline 116 & $73.36 \pm 0.17^{b}$ & $61.43 \pm 0.18^{a}$ & $51.27 \pm 0.43^{\mathrm{b}}$ & $81.97 \pm 0.34^{b}$ \\
\hline 143 & $121.46 \pm 0.26^{8}$ & $65.04 \pm 0.26^{a}$ & $80.42 \pm 0.46^{a}$ & $120.60 \pm 0.43^{a}$ \\
\hline Correlation with DDPH & $0.8968^{*}$ & $0.8924^{*}$ & $0.8355^{*}$ & $0.8199^{\star}$ \\
\hline Correlation with ABTS & $0.8423^{*}$ & $0.8620^{*}$ & 0.7797 & 0.7362 \\
\hline DAA & 'Grifa' & $\begin{array}{l}\text { Total phenolics content } \\
\text { (mg GAE/100 g FW) } \\
\text { 'Rojo Insurgentes' }\end{array}$ & 'Orejón' & 'Sangre de Toro' \\
\hline 15 & $55.17 \pm 0.36^{e}$ & $40.77 \pm 0.4^{f}$ & $59.25 \pm 0.17^{h}$ & $70.27 \pm 0.46^{e}$ \\
\hline 36 & $68.60 \pm 0.26^{e}$ & $50.64 \pm 0.17^{e}$ & $63.49 \pm 0.26^{g}$ & $75.14 \pm 0.55^{e}$ \\
\hline 49 & $89.92 \pm 0.17^{\mathrm{de}}$ & $53.28 \pm 0.55^{b}$ & $88.63 \pm 0.20^{f}$ & $114.51 \pm 0.30^{d}$ \\
\hline 63 & $141.03 \pm 0.62^{\mathrm{cd}}$ & $63.15 \pm 0.43^{d}$ & $93.22 \pm 0.20^{\mathrm{e}}$ & $117.21 \pm 0.26^{d}$ \\
\hline 77 & $143.78 \pm 0.30^{\mathrm{cd}}$ & $77.21 \pm 0.20^{c}$ & $110.96 \pm 0.40^{d}$ & $167.20 \pm 0.34^{c}$ \\
\hline 100 & $187.17 \pm 0.34^{b c}$ & $142.35 \pm 8.40^{b}$ & $213.17 \pm 0.52^{c}$ & $213.52 \pm 0.17^{b}$ \\
\hline 116 & $226.43 \pm 0.46^{\mathrm{ab}}$ & $173.74 \pm 0.34^{a}$ & $218.57 \pm 0.55^{b}$ & $220.69 \pm 0.36^{b}$ \\
\hline 143 & $257.77 \pm 0.17^{a}$ & $176.90 \pm 0.43^{a}$ & $247.84 \pm 0.55^{a}$ & $245.300 \pm 0.20^{a}$ \\
\hline Correlation with DDPH & $0.9399^{*}$ & $0.8549^{\star}$ & 0.7932 & $0.9119^{*}$ \\
\hline Correlation with ABTS & $0.9535^{*}$ & $0.9384^{*}$ & 0.7014 & $0.9675^{*}$ \\
\hline DAA & 'Cardona' & $\begin{array}{c}\text { Total phenolics content } \\
\text { (mg GAE/100 g FW) } \\
\text { 'Rojo Pelón' }\end{array}$ & 'Sandía' & 'Burra la Cruz' \\
\hline 15 & $70.49 \pm 0.60^{h}$ & $38.76 \pm 0.46^{c}$ & $51.44 \pm 0.53^{h}$ & $41.68 \pm 0 . s 17^{h}$ \\
\hline 36 & $82.06 \pm 0.26^{g}$ & $41.34 \pm 0.34^{c}$ & $55.97 \pm 0.17^{g}$ & $53.39 \pm 0.17^{g}$ \\
\hline 49 & $160.54 \pm 0.50^{f}$ & $64.93 \pm 0.17^{\mathrm{b}}$ & $118.24 \pm 0.53^{f}$ & $62.40 \pm 0.26^{f}$ \\
\hline 63 & $166.86 \pm 0.62^{\mathrm{e}}$ & $66.53 \pm 0.36^{b}$ & $120.80 \pm 0.09^{e}$ & $65.79 \pm 0.34^{e}$ \\
\hline 77 & $179.31 \pm 0.43^{d}$ & $68.77 \pm 0.43^{b}$ & $125.71 \pm 0.62^{d}$ & $92.25 \pm 0.36^{d}$ \\
\hline 100 & $216.79 \pm 0.34^{c}$ & $142.69 \pm 0.26^{a}$ & $197.68 \pm 0.30^{c}$ & $166.63 \pm 0.26^{c}$ \\
\hline 116 & $222.42 \pm 0.66^{\mathrm{b}}$ & $134.65 \pm 0.0 \mathrm{~s}^{\mathrm{a}}$ & $210.19 \pm 0.43^{b}$ & $183.96 \pm 0.70^{b}$ \\
\hline 143 & $239.23 \pm 0.53^{a}$ & $151.82 \pm 0.26^{a}$ & $227.46 \pm 0.52^{a}$ & $194.69 \pm 0.36^{a}$ \\
\hline Correlation with DDPH & $0.9588^{*}$ & $0.8651^{*}$ & 0.7995 & $0.9669^{*}$ \\
\hline Correlation with ABTS & $0.9560^{*}$ & 0.7583 & $0.8121^{*}$ & $0.8926^{*}$ \\
\hline
\end{tabular}

Means in each column with different letters are statistically different (Tukey, $P \leq 0.05$ ). *: Significant at $P \leq 0.05$. Values are means \pm standard deviations

the fruit changed from very immature to immature. The accessions RT and TA showed the most marked change between 116 and $143 \mathrm{DAA}$, when the fruits changed from moderately ripe to ripe. The concentration of flavonoids was significantly correlated (positively) with DPPH and/ or ABTS radical scavenging activity for almost all the accessions, except for $\mathrm{BO}$, which showed a significant correlation between pigments or TPC and DPPH or ABTS radical scavenging activity (as discussed above). The $\mathrm{BO}$ accession displayed a marked change in TFC between 77 and $100 \mathrm{DAA}$, when the fruits change from immature to under-ripe. Times at which the major changes occurred in TPC did not coincide with those occurred in TFC, this behavior can be displayed because flavonoids are not the unique type of phenolics present in prickly pear fruits. Opuntia spp. fruits contain flavonoids commonly found in other fruits and vegetables, the type of flavonoid and its content depends on the species and accession (Miean and Mohamed, 2001).

\section{Radical scavenging activity}

Independently of the assay (DPPH or ABTS), it was found an increment of the antioxidant activity along the ripening process. This increment was due to the presence of different kind of chemical compounds with antioxidant activity in prickly pear fruits. The study of correlation between the bioactive compounds presenting antioxidant activity and the DPPH or ABTS assay reveals that the free radical scavenging activity was dependent on the accession studied, since each one synthetizes different compounds at different stages of the ripening process, leading a higher antioxidant activity as the maturity occurs.

Results about DPPH assay showed an increment of the radical scavenging activity over the ripening process in the twelve accessions of prickly pear fruits studied (Table 4), for example, the radical scavenging activity for RT ranged from $1.25 \pm 0.02 \mu \mathrm{mol}$ TE/g FW at $15 \mathrm{DAA}$ to $6.30 \pm 0.02 \mu \mathrm{mol} \mathrm{TE} / \mathrm{g} \mathrm{FW}$ at $143 \mathrm{DAA}$. In fact, all 
Table 3: Evolution of total flavonoids content of twelve red prickly pear fruit accessions from very immature to ripe

\begin{tabular}{|c|c|c|c|c|}
\hline $\begin{array}{l}\text { Days after anthesis } \\
\text { (DDA) }\end{array}$ & 'Cacalote' & $\begin{array}{c}\text { Total flavonoids content } \\
\left.\text { (mg EQ } 100 \mathrm{~g}^{-1} \mathrm{FW}\right) \\
\text { 'Bonda' }\end{array}$ & 'Rojo Toluca' & 'Tapón Aguanoso' \\
\hline 15 & $1.90 \pm 0.06^{h}$ & $2.17 \pm 0.04^{h}$ & $1.97 \pm 0.06^{h}$ & $1.54 \pm 0.06^{h}$ \\
\hline 36 & $3.00 \pm 0.06^{g}$ & $2.41 \pm 0.03^{g}$ & $2.49 \pm 0.04^{\mathrm{g}}$ & $2.20 \pm 0.04^{g}$ \\
\hline 49 & $7.48 \pm 0.06^{\dagger}$ & $2.66 \pm 0.06^{t}$ & $3.00 \pm 0.07^{f}$ & $3.79 \pm 0.07^{b}$ \\
\hline 63 & $8.52 \pm 0.03^{e}$ & $3.30 \pm 0.06^{e}$ & $3.54 \pm 0.03^{e}$ & $6.61 \pm 0.04^{\dagger}$ \\
\hline 77 & $8.87 \pm 0.04^{d}$ & $4.00 \pm 0.07^{d}$ & $4.04 \pm 0.05^{d}$ & $7.07 \pm 0.07^{e}$ \\
\hline 100 & $9.51 \pm 0.04^{c}$ & $9.65 \pm 0.04^{c}$ & $8.11 \pm 0.07^{c}$ & $7.55 \pm 0.06^{d}$ \\
\hline 116 & $9.77 \pm 0.05^{\mathrm{b}}$ & $11.41 \pm 0.06^{b}$ & $12.06 \pm 0.04^{b}$ & $8.48 \pm 0.06^{c}$ \\
\hline 143 & $12.22 \pm 0.07^{a}$ & $12.28 \pm 0.04^{a}$ & $17.83 \pm 0.07^{\mathrm{g}}$ & $15.37 \pm 0.06^{a}$ \\
\hline Correlation with DDPH & $0.9322^{*}$ & 0.7871 & $0.8815^{\star}$ & $0.8427^{*}$ \\
\hline Correlation with ABTS & $0.8749^{*}$ & 0.7638 & 0.6769 & $0.8190^{*}$ \\
\hline DDA & 'Grifa' & $\begin{array}{l}\text { Total flavonoids content } \\
\left.\text { (mg EQ } 100 \mathrm{~g}^{-1} \mathrm{FW}\right) \\
\text { 'Rojo Insurgentes' }\end{array}$ & 'Orejón' & 'Sangre de Toro' \\
\hline 15 & $1.15 \pm 0.04^{\mathrm{h}}$ & $1.55 \pm 0.03^{h}$ & $1.86 \pm 0.05^{h}$ & $1.64 \pm 0.05^{h}$ \\
\hline 36 & $1.83 \pm 0.06^{g}$ & $1.83 \pm 0.03^{g}$ & $2.52 \pm 0.02^{\mathrm{g}}$ & $2.17 \pm 0.04^{\mathrm{g}}$ \\
\hline 49 & $5.79 \pm 0.06^{\dagger}$ & $3.33 \pm 0.07^{f}$ & $3.34 \pm 0.07^{f}$ & $7.45 \pm 0.04^{\dagger}$ \\
\hline 63 & $7.66 \pm 0.06^{e}$ & $6.00 \pm 0.04^{e}$ & $6.11 \pm 0.06^{\mathrm{e}}$ & $7.84 \pm 0.02^{\mathrm{e}}$ \\
\hline 77 & $8.39 \pm 0.07^{d}$ & $7.75 \pm 0.04^{d}$ & $9.15 \pm 0.02^{d}$ & $8.01 \pm 0.06^{d}$ \\
\hline 100 & $8.90 \pm 0.03^{c}$ & $9.13 \pm 0.03^{c}$ & $9.66 \pm 0.03^{c}$ & $9.74 \pm 0.07^{c}$ \\
\hline 116 & $12.91 \pm 0.08^{b}$ & $14.88 \pm 0.06^{b}$ & $17.39 \pm 0.08^{b}$ & $13.02 \pm 0.07^{b}$ \\
\hline 143 & $13.96 \pm 0.03^{a}$ & $15.54 \pm 0.06^{\mathrm{a}}$ & $19.45 \pm 0.07^{\mathrm{a}}$ & $15.32 \pm 0.10^{a}$ \\
\hline Correlation with DDPH & $0.9372^{*}$ & $0.9162^{*}$ & $0.8091^{*}$ & $0.9571^{*}$ \\
\hline Correlation with ABTS & $0.9654^{*}$ & $0.9431^{*}$ & 0.7096 & $0.9377^{*}$ \\
\hline DDA & 'Cardona' & $\begin{array}{c}\text { Total flavonoids content } \\
\left.\text { (mg EQ } 100 \mathrm{~g}^{-1} \mathrm{FW}\right) \\
\text { 'Rojo Pelón' }\end{array}$ & 'Sandía' & 'Burra la Cruz' \\
\hline 15 & $1.12 \pm 0.10^{\mathrm{h}}$ & $1.19 \pm 0.05^{h}$ & $0.56 \pm 0.02^{h}$ & $1.55 \pm 0.06^{h}$ \\
\hline 36 & $1.88 \pm 0.07^{g}$ & $2.00 \pm 0.07^{g}$ & $1.78 \pm 0.07^{g}$ & $2.49 \pm 0.07^{g}$ \\
\hline 49 & $7.81 \pm 0.08^{f}$ & $4.35 \pm 0.07^{f}$ & $3.86 \pm 0.06^{t}$ & $7.15 \pm 0.08^{f}$ \\
\hline 63 & $8.97 \pm 0.08^{e}$ & $7.65 \pm 0.04^{e}$ & $6.38 \pm 0.03^{e}$ & $8.74 \pm 0.06^{e}$ \\
\hline 77 & $10.13 \pm 0.07^{d}$ & $8.60 \pm 0.08^{d}$ & $6.79 \pm 0.08^{d}$ & $9.06 \pm 0.04^{d}$ \\
\hline 100 & $10.78 \pm 0.06^{c}$ & $9.71 \pm 0.08^{c}$ & $7.60 \pm 0.04^{c}$ & $9.52 \pm 0.06^{c}$ \\
\hline 116 & $17.54 \pm 0.07^{b}$ & $16.59 \pm 0.06^{b}$ & $16.92 \pm 0.08^{b}$ & $12.66 \pm 0.06^{b}$ \\
\hline 143 & $19.10 \pm 0.07^{\mathrm{a}}$ & $18.31 \pm 0.10^{\mathrm{a}}$ & $18.17 \pm 0.07^{\mathrm{a}}$ & $13.31 \pm 0.11^{\mathrm{a}}$ \\
\hline Correlation with DDPH & $0.9588^{*}$ & $0.8999^{*}$ & 0.7995 & $0.9479^{*}$ \\
\hline Correlation with ABTS & $0.9331^{*}$ & $0.8092^{*}$ & $0.8121^{*}$ & $0.9572^{*}$ \\
\hline
\end{tabular}

Means in each column with different letters are statistically different (Tukey, $P \leq 0.05$ ). *: Significant at $P \leq 0.05$. Values are means \pm standard deviations

the accessions reached a similar value of free radical scavenging capacity at $143 \mathrm{DAA}$ (when ripe), ranging from $5.77 \pm 0.03 \mu \mathrm{mol} \mathrm{TE} / \mathrm{g} F W$ for $\mathrm{BC}_{143}$ to $6.60 \pm 0.02$ for $\mathrm{GR}_{143}$. Correlation of TPC or TFC with DPPH was significant for almost all the accessions, except for the SA accession, which was significantly correlated only with ABTS.

Results about ABTS assay (Table 5) were expressed in the same units used for DPPH in order to make a better comparison between them. It was found the same trend in ABTS than DPPH assay over the ripening process. Nevertheless, the ABTS assay displayed higher values of radical scavenging activity when compared with DPPH. For the same example given above, $\mathrm{RT}_{15}$ displayed $2.69 \pm 0.03 \mu \mathrm{mol} \mathrm{TE} / \mathrm{g} \mathrm{FW}$ increasing until $9.19 \pm$ $0.02 \mu \mathrm{mol} \mathrm{TE} / \mathrm{g} \mathrm{FW}$ for $\mathrm{RT}_{143}$. For ABTS assay, as in $\mathrm{DPPH}$, all the accessions reached a similar value of free radical scavenging capacity at $143 \mathrm{DAA}$, ranging from $8.06 \pm 0.02 \mu \mathrm{mol} \mathrm{TE} / \mathrm{g} \mathrm{FW}$ for $\mathrm{TA}_{143}$ to that shown in
$\mathrm{RT}_{143}$. These greater values found when the ABTS radical was used can be explained by the higher selectivity of the DPPH radical. The ABTS radical reacts with any hydroxylated aromatic molecule, independently of its real antioxidant potential (Kopjar et al., 2015).

\section{CONCLUSIONS}

The antioxidant activity of prickly pear fruits increases along the ripening process, this increment is positively correlated with the increase in concentration of the bioactive compounds present in fruits such as phenolics, flavonoids and pigments. The pigments appeared in different stages of the ripening process, depending on the accession studied, nevertheless, once the fruit is ripe, their concentration remains constant. This fact makes possible to propose the measurement of betalains concentration as a parameter of ripeness, additionally to traditional parameters as total soluble solids concentration, titratable acidity and 
Table 4: Evolution of DPPH radical scavenging capacity of twelve red prickly pear fruits from very immature to ripe

\begin{tabular}{|c|c|c|c|c|}
\hline $\begin{array}{l}\text { Days after anthesis } \\
\text { (DAA) }\end{array}$ & 'Cacalote' & $\begin{array}{c}\text { DPPH radical scavenging capacity } \\
(\mu \mathrm{mol} \text { TE/g FW }) \\
\text { 'Bonda' }\end{array}$ & 'Rojo Toluca' & $\begin{array}{c}\text { 'Tapón } \\
\text { Aguanoso' }\end{array}$ \\
\hline 15 & $2.69 \pm 0.03^{9}$ & $2.46 \pm 0.03^{g}$ & $1.25 \pm 0.02^{g}$ & $3.07 \pm 0.04$ \\
\hline 36 & $2.60 \pm 0.03^{h}$ & $3.69 \pm 0.03^{f}$ & $1.61 \pm 0.04^{\dagger}$ & $4.00 \pm 0.03^{e}$ \\
\hline 49 & $3.89 \pm 0.02^{f}$ & $4.53 \pm 0.04^{e}$ & $2.07 \pm 0.02^{\mathrm{e}}$ & $4.30 \pm 0.02^{d}$ \\
\hline 63 & $3.98 \pm 0.03^{e}$ & $4.90 \pm 0.02^{d}$ & $2.34 \pm 0.04^{d}$ & $4.49 \pm 0.02^{c}$ \\
\hline 77 & $4.52 \pm 0.01^{d}$ & $6.14 \pm 0.01^{c}$ & $5.19 \pm 0.02^{c}$ & $5.94 \pm 0.01^{b}$ \\
\hline 100 & $4.62 \pm 0.03^{c}$ & $6.28 \pm 0.02^{b}$ & $5.77 \pm 0.03^{b}$ & $5.97 \pm 0.01^{b}$ \\
\hline 116 & $5.75 \pm 0.02^{b}$ & $6.32 \pm 0.02^{b}$ & $6.24 \pm 0.01^{c}$ & $5.99 \pm 0.01^{b}$ \\
\hline 143 & $6.48 \pm 0.03^{a}$ & $6.54 \pm 0.03^{a}$ & $6.30 \pm 0.02^{d}$ & $6.07 \pm 0.01^{a}$ \\
\hline DAA & 'Grifa' & $\begin{array}{c}\text { DPPH radical scavenging capacity } \\
\text { ( } \mu \mathrm{mol} \text { TE/g FW) } \\
\text { 'Rojo Insurgentes' }\end{array}$ & 'Orejón' & 'Sangre de Toro' \\
\hline 15 & $3.34 \pm 0.03^{h}$ & $3.58 \pm 0.04^{h}$ & $3.26 \pm 0.05^{h}$ & $3.00 \pm 0.03^{h}$ \\
\hline 36 & $4.49 \pm 0.04^{g}$ & $4.11 \pm 0.04^{\mathrm{g}}$ & $4.11 \pm 0.04^{\mathrm{g}}$ & $3.98 \pm 0.05^{g}$ \\
\hline 49 & $5.19 \pm 0.02^{\dagger}$ & $5.02 \pm 0.04^{t}$ & $4.73 \pm 0.02^{f}$ & $4.49 \pm 0.03^{f}$ \\
\hline 63 & $5.44 \pm 0.04^{e}$ & $5.33 \pm 0.02^{e}$ & $6.01 \pm 0.01^{\mathrm{e}}$ & $4.73 \pm 0.02^{e}$ \\
\hline 77 & $5.67 \pm 0.02^{d}$ & $5.46 \pm 0.03^{d}$ & $6.21 \pm 0.02^{d}$ & $4.93 \pm 0.02^{d}$ \\
\hline 100 & $6.35 \pm 0.02^{c}$ & $5.76 \pm 0.02^{c}$ & $6.37 \pm 0.02^{c}$ & $5.08 \pm 0.02^{c}$ \\
\hline 116 & $6.46 \pm 0.01^{b}$ & $6.12 \pm 0.02^{b}$ & $6.46 \pm 0.01^{b}$ & $5.53 \pm 0.02^{b}$ \\
\hline 143 & $6.60 \pm 0.02^{\mathrm{a}}$ & $6.42 \pm 0.01^{\mathrm{a}}$ & $6.57 \pm 0.02^{\mathrm{a}}$ & $5.99 \pm 0.01^{\mathrm{B}}$ \\
\hline DAA & 'Cardona' & $\begin{array}{c}\text { DPPH radical scavenging capacity } \\
\text { ( } \mu \text { mol TE/g FW) } \\
\text { 'Rojo Pelón' }\end{array}$ & 'Sandía' & 'Burra la Cruz' \\
\hline 15 & $1.98 \pm 0.03^{h}$ & $2.64 \pm 0.05^{g}$ & $3.98 \pm 0.05^{9}$ & $1.25 \pm 0.02^{h}$ \\
\hline 36 & $2.60 \pm 0.03^{g}$ & $3.26 \pm 0.04^{t}$ & $4.73 \pm 0.02^{\dagger}$ & $1.98 \pm 0.03^{\mathrm{g}}$ \\
\hline 49 & $3.16 \pm 0.03^{t}$ & $3.94 \pm 0.03^{e}$ & $5.45 \pm 0.03^{e}$ & $2.88 \pm 0.03^{\dagger}$ \\
\hline 63 & $3.67 \pm 0.02^{\mathrm{e}}$ & $4.42 \pm 0.02^{d}$ & $6.15 \pm 0.03^{d}$ & $3.22 \pm 0.03^{e}$ \\
\hline 77 & $4.65 \pm 0.02^{d}$ & $5.87 \pm 0.02^{c}$ & $6.15 \pm 0.02^{d}$ & $3.57 \pm 0.02^{d}$ \\
\hline 100 & $5.21 \pm 0.01^{c}$ & $6.01 \pm 0.01^{b}$ & $6.26 \pm 0.02^{c}$ & $5.15 \pm 0.02^{c}$ \\
\hline 116 & $5.92 \pm 0.02^{b}$ & $6.26 \pm 0.03^{a}$ & $6.42 \pm 0.01^{b}$ & $5.52 \pm 0.01^{b}$ \\
\hline 143 & $6.15 \pm 0.06^{a}$ & $6.30 \pm 0.02^{\mathrm{a}}$ & $6.57 \pm 0.03^{a}$ & $5.77 \pm 0.03^{a}$ \\
\hline
\end{tabular}

Means in each column with different letters are statistically different (Tukey, $P \leq 0.05)$. Values are means \pm standard deviations

Table 5: Evolution of ABTS radical scavenging capacity of twelve red prickly pear fruit accessions from very immature to ripe

\begin{tabular}{|c|c|c|c|c|}
\hline $\begin{array}{l}\text { Days after anthesis } \\
\text { (DAA) }\end{array}$ & 'Cacalote' & $\begin{array}{c}\text { ABTS radical scavenging capacity } \\
(\mu \mathrm{mol} \text { TE/g FW) } \\
\text { 'Bonda' }\end{array}$ & 'Tapón aguanoso' & 'Rojo Toluca' \\
\hline 15 & $5.06 \pm 0.03^{h}$ & $5.07 \pm 0.04^{9}$ & $2.69 \pm 0.03^{9}$ & $5.20 \pm 0.04^{g}$ \\
\hline 36 & $5.18 \pm 0.04^{9}$ & $5.89 \pm 0.05^{\dagger}$ & $3.05 \pm 0.05^{f}$ & $5.59 \pm 0.02^{f}$ \\
\hline 49 & $5.88 \pm 0.02^{f}$ & $6.37 \pm 0.02^{\mathrm{e}}$ & $6.75 \pm 0.03^{e}$ & $5.83 \pm 0.02^{\mathrm{e}}$ \\
\hline 63 & $6.00 \pm 0.03^{e}$ & $7.99 \pm 0.01^{d}$ & $7.51 \pm 0.03^{d}$ & $7.72 \pm 0.01^{d}$ \\
\hline 77 & $7.48 \pm 0.02^{d}$ & $8.16 \pm 0.03^{c}$ & $8.12 \pm 0.01^{c}$ & $7.76 \pm 0.01^{\text {cd }}$ \\
\hline 100 & $8.42 \pm 0.04^{c}$ & $8.22 \pm 0.03^{c}$ & $8.19 \pm 0.03^{c}$ & $7.78 \pm 0.01^{c}$ \\
\hline 116 & $8.66 \pm 0.03^{b}$ & $8.50 \pm 0.04^{b}$ & $8.47 \pm 0.02^{b}$ & $7.89 \pm 0.01^{b}$ \\
\hline 143 & $8.82 \pm 0.03^{a}$ & $8.78 \pm 0.03^{a}$ & $9.19 \pm 0.02^{\mathrm{a}}$ & $8.06 \pm 0.02^{\mathrm{a}}$ \\
\hline DAA & 'Grifa' & $\begin{array}{c}\text { ABTS radical scavenging capacity } \\
\text { ( } \mu \mathrm{mol} \text { TE/g FW) } \\
\text { 'Rojo Insurgentes' }\end{array}$ & 'Orejón' & 'Sangre de Toro' \\
\hline 15 & $7.31 \pm 0.03^{g}$ & $6.53 \pm 0.05^{9}$ & $6.15 \pm 0.03^{\text {h }}$ & $5.84 \pm 0.04^{\mathrm{h}}$ \\
\hline 36 & $7.37 \pm 0.02^{g}$ & $6.93 \pm 0.03^{f}$ & $7.81 \pm 0.01^{g}$ & $6.30 \pm 0.03^{g}$ \\
\hline 49 & $8.14 \pm 0.03^{t}$ & $7.10 \pm 0.03^{e}$ & $8.07 \pm 0.02^{f}$ & $6.41 \pm 0.02^{f}$ \\
\hline 63 & $8.25 \pm 0.03^{e}$ & $7.10 \pm 0.02^{\mathrm{e}}$ & $8.29 \pm 0.03^{e}$ & $6.61 \pm 0.03^{e}$ \\
\hline 77 & $8.40 \pm 0.02^{d}$ & $7.96 \pm 0.02^{d}$ & $8.40 \pm 0.01^{d}$ & $7.19 \pm 0.02^{d}$ \\
\hline 100 & $8.58 \pm 0.02^{c}$ & $8.28 \pm 0.02^{c}$ & $8.54 \pm 0.02^{c}$ & $7.73 \pm 0.03^{c}$ \\
\hline 113 & $8.70 \pm 0.02^{b}$ & $8.41 \pm 0.02^{b}$ & $8.70 \pm 0.02^{b}$ & $8.55 \pm 0.03^{b}$ \\
\hline 143 & $8.85 \pm 0.02^{\mathrm{a}}$ & $8.79 \pm 0.03^{a}$ & $8.81 \pm 0.03^{a}$ & $8.81 \pm 0.02^{\mathrm{a}}$ \\
\hline DAA & 'Cardona' & $\begin{array}{c}\text { ABTS radical scavenging capacity } \\
\text { ( } \mu \text { mol TE/g FW) } \\
\text { 'Rojo Pelón' }\end{array}$ & 'Sandía' & 'Burra la Cruz' \\
\hline 15 & $4.11 \pm 0.04^{g}$ & $5.12 \pm 0.04^{f}$ & $7.08 \pm 0.03^{f}$ & $3.74 \pm 0.04^{h}$ \\
\hline 36 & $4.77 \pm 0.02^{f}$ & $5.75 \pm 0.02^{e}$ & $7.99 \pm 0.03^{e}$ & $4.19 \pm 0.03^{g}$ \\
\hline
\end{tabular}


Table 5: (Continued)

\begin{tabular}{lcccc}
\hline DAA & 'Cardona' & $\begin{array}{c}\text { ABTS radical scavenging capacity } \\
(\mu \mathrm{mol} \text { TE/g FW) } \\
\text { 'Rojo pelón' }\end{array}$ & 'Sandía' 'Burra la cruz' \\
\hline 49 & $6.05 \pm 0.02^{\mathrm{e}}$ & $7.63 \pm 0.03^{\mathrm{d}}$ & $8.00 \pm 0.03^{\mathrm{e}}$ & $4.65 \pm 0.03^{\mathrm{f}}$ \\
63 & $6.77 \pm 0.01^{\mathrm{d}}$ & $7.81 \pm 0.01^{\mathrm{c}}$ & $8.14 \pm 0.02^{\mathrm{d}}$ & $6.69 \pm 0.02^{\mathrm{e}}$ \\
77 & $7.69 \pm 0.03^{\mathrm{c}}$ & $8.14 \pm 0.03^{\mathrm{b}}$ & $8.35 \pm 0.01^{\mathrm{c}}$ & $7.17 \pm 0.01^{\mathrm{d}}$ \\
100 & $7.99 \pm 0.08^{\mathrm{b}}$ & $8.18 \pm 0.02^{\mathrm{b}}$ & $8.61 \pm 0.03^{\mathrm{b}}$ & $7.43 \pm 0.03^{\mathrm{c}}$ \\
116 & $8.02 \pm 0.04^{\mathrm{b}}$ & $8.42 \pm 0.03^{\mathrm{a}}$ & $8.72 \pm 0.01^{\mathrm{a}}$ & $8.40 \pm 0.01^{\mathrm{b}}$ \\
143 & $8.80 \pm 0.02^{\mathrm{a}}$ & $8.43 \pm 0.03^{\mathrm{a}}$ & $8.73 \pm 0.01^{\mathrm{a}}$ & $8.79 \pm 0.03^{\mathrm{a}}$ \\
\hline
\end{tabular}

Means in each column with different letters are statistically different (Tukey, $P \leq 0.05$ ). Values are means \pm standard deviations

color. It is hoped that this work contributes to select the accessions with the better potential to be established in arid zones of Mexico in order to take in advantage these fruits as an important source of pigments. Moreover, this work can contribute to the knowledge of the stage of the ripening process at which would be possible to obtain a major concentration of bioactive compounds taking as reference the anthesis.

\section{ACKNOWLEDGEMENTS}

The authors thank FOMIX-CONACYT-HIDALGO for the financial support (project number 195462).

\section{Author's contributions}

J.M.P.E: Carried out the experiments. C.L.A.M: Supervised and planned the research. R.J.A: Wrote the manuscript and was involved in critical revision. J.C.R.P: Designed experimental procedures and did the statistical analyses. G.I. de la F: Participate in the supervision and critical revision. J.G.R.P: Harvested the prickly pear accessions and did their selection and classification. A.D.H.F: Proposed the research topic, was involved in the overall planning and supervision, and submitted the manuscript.

\section{REFERENCES}

Arvouet-Grand, A., B. Vennat, A. Pourrat and P. Legret. 1994. Standardization d'une extrait de propolis et identification des principaux constituents. J. Pharm. Belg. 49: 462-468.

Belhadj, F., I. Somrani, N. Aissaoui, C. H. Messaoud, M. Boussaid and M. N. Marzouki. 2016. Bioactive compounds contents, antioxidants and antimicrobial activities during ripening of Prunus persica L. Varieties from the North West of Tunisia. Food Chem. 204: 29-36.

Bensadón, S., D. Hervert-Hernández, S. G. Sáyago-Ayerdi and I. Goñi. 2010. By-products of Opuntia ficus-indica as a source of antioxidant dietary fiber. Plant Food Hum. Nutr. 65: 210-216.

Brand-Williams, W., M. E. Cuvelier and C. Berset. 1995. Use of a free radical method to evaluate antioxidant activity. LWT-Food Sci. Technol. 28(1): 25-30.

Cantin, C. M., M. A. Moreno and Y. Gogorcena. 2009. Evaluation of the antioxidant capacity, phenolic compounds, and vitamin C content of different peach and nectarine [Prunus persica (L.) Batsch] breeding progenies. J. Agric. Food Chem. 57(11): 4586-4592.

Castellar, M. R., J. M. Obón, M. Alacid and J. A. Fernández-López. 2003. Color properties and stability of betacyanins from Opuntia fruits. J. Agric. Food Chem. 51: 2772-2776.

Castellar, M., R. Obón, J. M. Alacid and J. A. Fernández-López. 2006. The isolation and properties of a concentrated red-purple betacyanin food colorant from Opuntia stricta fruits. J. Sci. Food Agric. 86: 122-128.

Felker, P., F. C. E. Stintzing, E. Müssig, M. Leitenberger, R. Carle, T. Vogt and R. Bunch. 2008. Colour inheritance in cactus pear (Opuntia ficus-indica) fruits. Ann. Appl. Biol. 152: 307-318.

Fernández-López, J. A., L. Almela, J. M. Obón and M. R. Castellar. 2010. Determination of antioxidant constituents in cactus pear fruits. Plant. Food Hum. Nutr. 65: 253-259.

Gil, M. I., F. A. Tomás-Barberán, B. Hess-Pierce and A. A. Kader. 2002. Antioxidant capacities, phenolic compounds, carotenoids and vitamin $\mathrm{C}$ contents of nectarine, peach and plum cultivars from California. J. Agric. Food Chem. 50(17): 4976-4982.

Kopjar, M., M. Tadić and V. Piližota. 2015. Phenol content and antioxidant activity of green, yellow and black tea leaves. Chem. Biol. Technol. Agric. 2: 1-6.

Kujala, T., J. Loponen and K. Pihlaja. 2001. Betalains and phenolics in red beet root (Beta vulgaris) peel extracts: Extraction and characterization. Z. Naturforsch B. 56: 343-348.

Kujala, T. S., M. S. Vienola, K. D. Klika, J. M. Loponen and K. Pihlaja. 2002. Betalain and phenolic compositions of four beetroot (Beta vulgaris) cultivars. Eur. Food Res. Technol. 214: 505-510.

Livrea, M. A. and L. Tesoriere. 2006. Health benefits and bioactive components of the fruits from Opuntia ficus-indica (L.) Mill. J. Prof. Assoc. Cactus. 8: 73-90.

Miean, K. H. and S. Mohamed. 2001. Flavonoid (myricetin, quercetin, kaempferol, luteolin and apigenin) content of edible tropical plants. J. Agric. Food Chem. 49: 3106-3112.

Moßhammer, M. R., F. C. Stintzing and R. Carle. 2005. Development of a process for the production of a betalain-based colouring foodstuff from cactus pear. Innov. Food Sci. Emerg. 6(2): 221-231.

Obón, J. M., M. R. Castellar, M. Alacid and J. A. Fernández-López. 2009. Production of a red-purpled food colorant from Opuntia stricta fruits by spray drying and its application in food model systems. J. Food Eng. 90: 471-479.

Pimienta, E. 2001. Preface. In: Mondragon-Jacobo, C. and S. PérezGonzález, (Ed.), Cactus (Opuntia spp.) As Forage. FAO Plant Production and Protection Paper No. 169, FAO, Rome.

Re, R., N. Pellegrini, A. Proteggente, A. Pannala, M. Yanga and C. A. Rice-Evans. 1999. Antioxidant activity applying an improved ABTS radical cation decolorization assay. Free Radic. Biol. Med. 26: 1231-1237.

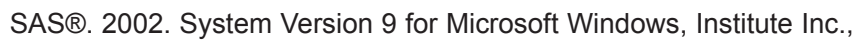


Cary, North Carolina, USA.

Stintzing, F. C., A. Schieber and R. Carle. 2002. Betacyanins in fruits of deep-purple pitaya, Hylocereus polyrhizus (Weber) Britton \& Rose. Food Chem. 77: 101-106.

Stintzing, F. C. and R. Carle. 2005. Cactus stems (Opuntia spp.): A review on their chemistry, technology, and uses. Mol. Nutr. Food Res. 49(2): 175-194.

Stintzing, F. C. and R. Carle. 2007. Betalains emerging prospects for food scientists. Trends Food Sci. Technol. 18: 514-525.

Sumaya-Martínez, M. T., S. Cruz-Jaime, E. Madrigal-Santillán, J. D. García-Paredes, R. Cariño-Cortés, N. Cruz-Cansino, C. Valadez-Vega, L. Martínez-Cárdenas and E. Alanís-García. 2011. Betalain, acid ascorbic, phenolic contents and antioxidant properties of purple, red, yellow and white cactus pears. Int. J. Mol. Sci. 12: 6152-6168.

Tesoriere, L., M. Fazzari, M. Allegra and M. A. Livrea. 2005. Biothiols, taurine, and lipid- soluble antioxidants in the edible pulp of Sicilian cactus pear (Opuntia ficus-indica) fruits and changes of bioactive juice components upon industrial processing. J. Agric. Food Chem. 53: 7851-7855.

Tsai, P. J., Y. S. Chen, C. H. Sheu and C. Y. Chen. 2011. Effect of nanogrinding on the pigment and bioactivity of djulis (Chenopodium formosanum Koidz.). J. Agric. Food Chem. 59: 1814-1820.

Waterman, P. and S. Mole. 1994. Analysis of Phenolic Plant Metabolites, Blackwell Scientific Publications, UK, p238. 